\title{
Triggers for the Impoverishment of the Macroinvertebrate Communities in the Human-Impacted Rivers of Two Central European Ecoregions
}

\author{
Dariusz Halabowski - Iga Lewin (D)
}

Received: 15 October 2020 / Accepted: 21 January 2021 / Published online: 4 February 2021

(C) The Author(s) 2021

\begin{abstract}
Human activity triggers negative alternations in river habitats, including changes to the physical and chemical parameters of the water, its hydromorphological features and the introduction and spread of invasive alien species. These modifications are expected to be intensified by climate change. Eight rivers in one of the most urbanised and industrialised regions in Europe, i.e. the Upper Silesian Coal Basin, were surveyed in order to explain the impact of anthropopressure on the distribution of macroinvertebrates. Conductivity, altitude, hydromorphological transformations, hardness, the organic matter content and certain fractions of benthic sediments significantly affect $(p<0.01)$ the occurrence of macroinvertebrates in Central European rivers. Our results proved that the hydromorphological transformation of watercourses, which is expressed by the relevant indices, is one of the most predictive factors that contribute to the distribution of macroinvertebrates. Anthropogenic inland waters that have been salinised by the discharge of hard coal mine waters create new habitats for brackish and marine species that replace native freshwater species. An increase in salinity causes an impoverishment of macroinvertebrate biodiversity therefore all possible actions should be taken to reduce the anthropogenic salinity of inland waters. Secondary
\end{abstract}

D. Halabowski $(\bowtie) \cdot$ I. Lewin

Institute of Biology, Biotechnology and Environmental

Protection, Faculty of Natural Sciences, University of Silesia in

Katowice, Bankowa 9, 40-007 Katowice, Poland

e-mail: dariusz.halabowski@us.edu.pl saline rivers may prove to be prescient for climateinduced changes to river macroinvertebrates.

Keywords Anthropogenic salinisation · Human impact . Hydromorphological Index for Rivers · Invasive alien species $\cdot$ Pollution $\cdot$ Running waters

\section{Introduction}

Global biodiversity is now at the beginning of the sixth mass extinction of species. Projections indicate that approximately $75 \%$ of species may be lost due to this human-induced, global ecological crisis (Ceballos et al. 2015; Payne et al. 2016; Briggs 2017). Ten key factors, the so-called big killers (Maxwell et al. 2016), have been implicated in the accelerating the loss of biodiversity worldwide: overexploitation, agricultural activity, urban development, invasion and disease, pollution, system modification, climate change, human disturbance, transportation and energy production. Almost all of these "big killers" impact species dependent on freshwater environments - environments themselves that are the most threatened ecosystems on earth (Nieto et al. 2017).

In freshwater environments, nearly $10 \%$ of all known species are present (Winemiller 2018). This includes approximately one-third of known vertebrates and more than 2\% (> 150000 species) of global invertebrate biodiversity (Strayer 2006; Dudgeon et al. 2007). Changes in the physical and chemical characters of water along with the hydromorphological (e.g. riverbeds, water regime, connection with floodplain) 
degradation of rivers are direct threats to freshwater invertebrate diversity worldwide. In addition, anthropogenically derived point and diffuse pollution sources impact the diversity and abundance of macroinvertebrates. Anthropogenic salinisation is increasingly recognised as contributing to the degradation of water quality worldwide and represents a growing ecological threat to rivers and streams (CañedoArgüelles et al. 2013).

Hydromorphological transformations of most streams and rivers in Europe constitute one of the major threats to the habitats of mussels (Geist 2014). The removal of weeds and dredging of riverbeds, and above all channelisation and dams, alter the characteristics of aquatic ecosystems, disrupt the natural meta-population structure and contribute to local macroinvertebrate extirpations (Aldridge 2000; Cosgrove and Hastie 2001; Geist and Kuehn 2005).

Freshwater environments have long been experiencing the dangers of human activity, but in recent years, this process has been intensifying as urbanisation progress and the human population increases (Amoatey and Baawain 2019; Kumaraswamy et al. 2020). In recent years, anthropogenic salinisation has been considered one of the key factors contributing to the decrease of water quality worldwide (Cañedo-Argüelles et al. 2013). Nowadays, the major contributors to freshwater pollution include wastewater and industrial effluents, metals and metalloids, flame retardants, polycyclic aromatic hydrocarbons, nutrients and persistent organic pollutants, herbicides, pesticides, pharmaceuticals and illicit drugs and endocrine disruptors. In addition, new emerging pollutant sources in freshwater such as microplastics and engineered nanoparticles are being discovered (Amoatey and Baawain 2019). These changes in pollution affect the ecosystem functions of clean water for humanity and also affect aquatic biota (including macroinvertebrates) and may affect their ecological services (Cañedo-Argüelles et al. 2016; Lopes-Lima et al. 2017; Schmeller et al. 2018; Amoatey and Baawain 2019; Berger et al. 2019; Kumaraswamy et al. 2020). For example, heavy metals and the organochlorine insecticide DDT can affect the calcification and formation of mussel shells (Pynnönen 1995; LopesLima et al. 2017). Phosphorous and nitrogen concentrations are higher and are increasing in most European wetlands (Galloway et al. 2008; Douda 2010; Grizzetti et al. 2011). The deposition of fine-sediments and the introduction of nutrients from agricultural run-off are considered major threats to the most endangered freshwater macroinvertebrates such as mussels (Geist and Auerswald 2007; Lopes-Lima et al. 2017). Anthropogenic (secondary) salinisation is responsible for the degradation of water quality on a worldwide scale and results in biological changes in ecosystems, mainly in freshwater biota (Bäthe and Coring 2011; Kang and King 2012; Arle and Wagner 2013; Bąk et al. 2020; Sowa et al. 2020). In addition, dioxins, pharmaceutical compounds and other chemicals can have chronic and acute effects on aquatic macroinvertebrates (Lopes-Lima et al. 2017).

Climate change impacts abiotic factors including temperature and precipitation, which in turn, affect the functioning of aquatic ecosystems including the rate of reproduction and feeding of freshwater organisms (Vörösmarty et al. 2000; Schmeller et al. 2018). Both climate change and the anthropogenic degradation of water ecosystems contribute to the reduction in the quality and quantity of freshwater resources. Together with the increase in human population, they intensify the large-scale phenomenon of the impoverishment of biodiversity of freshwater environments (Vörösmarty et al. 2000; Malmqvist and Rundle 2002; Dudgeon et al. 2007). What is more, because of the interaction between global climate change and the anthropogenic alterations of the hydrologic cycle, secondary salinisation may become more intense in the coming decades (Neubauer and Craft 2009). Anthropogenic salinisation can degrade wetlands, affect a variety of the processes and dynamics of water environments and the ecosystem services that are provided by freshwater (Herbert et al. 2015).

However, the scientific understanding of the mechanisms by which increasing salinity destroys freshwater ecosystems is poor, which makes protecting freshwater habitats difficult (Cañedo-Argüelles et al. 2016). Referring to the above arguments, research on the factors that impact the changes in freshwater biodiversity in the age of climate change and environmental emergency have substantial value in the policy and decisionmaking processes of administrations and other stakeholders about the risk of climate change and the potential impact on human well-being (Lioy and Smith 2013)

Europe is divided into 25 ecoregions on the basis of the fauna living in European inland waters. The European Union Water Framework Directive (EU 
WFD) (Directive 2000) uses abiotic variables to classify streams and rivers into types. For rivers, the Directive fixed the typology, i.e. "System A" typology is defined by the ecoregions and size based on the catchment area, catchment geology and altitude. Therefore, based on the "System A" typology, the homogenous water bodies for the sampling sites were selected in accordance with the above requirements of the Directive including the ecoregions (Directive 2000).

The objectives of our survey were to analyse the structure of the macroinvertebrate communities in rivers that are located in one of the most industrialised and urbanised regions in Europe and to determine the most predictive environmental factors that affect the structure of macroinvertebrate communities. The physical, chemical and hydromorphological human pressure on the macroinvertebrate communities in various abiotic types of rivers have rarely been studied at the same time including the most salinised river in the world by the discharge of underground coal mine water. We hypothesise that the physical and chemical anthropogenic transformations are more important than the hydromorphological transformations in explaining the distribution of macroinvertebrates in the selected human-impacted Central European rivers.

\section{Materials and Methods}

\subsection{Study Area and Site Selection}

The research was carried out from 2017 to 2018 in Upper Silesia and adjacent areas (Southern Poland), which comprise part of the Central Plains (Ecoregion 14) and the Carpathians (Ecoregion 10) according to the division of the EU WFD (Directive 2000) (Fig. 1). The initial field recognition (site visits) and selection of sampling sites took place in 2016 prior to the fundamental field survey. The degree of human pressure was determined based on preliminary field surveys and the reports on ecological status of rivers obtained from the Voivodeship Inspectorates of Environmental Protection, Katowice and Cracow, Poland.

The research area included both protected areas and the most urbanised and industrialised region, i.e. the Upper Silesian Coal Basin (USCB), which is one of the largest hard coal mining areas in the world. Hard coal has been exploited in the USCB since 1740 (Dulias
2016). About 65 underground coal mines have been discharging the saline mine waters of Carboniferous rocks that have high concentrations of salts (mainly chlorides and sulphates) via the coal mine dewatering systems into the tributaries of the Vistula and Oder rivers, which caused their deterioration by the last decades of the twentieth century. Nowadays, about 35 hard coal mines are still active in the USCB. However, even after hard coal mines are closed, the saline mine waters are still discharged into the surface waters including rivers in order to eliminate the flooding risk to adjacent coal mine workings (Strozik 2017).

Eight rivers of four abiotic types, which are under different anthropogenic pressures, were selected in the catchments of the Vistula and Oder rivers within two ecoregions, i.e. the Central Plains and the Carpathians (Table 1). Two sampling sites (one in the upper course and one in the lower course) were selected for each river depending on the degree of anthropopressure. The sampling site in the upper course of each river (reference sampling site) was characterised by the absence or smaller scale of hydromorphological transformations including the degree of regulation of the river, more natural forms of land use and the lower values of the physical and chemical parameters of the water (e.g. conductivity, salinity or the concentrations of nutrients) compared with the sampling site located in the lower course. A total of 16 sampling sites are located according to the gradient of human pressure (Table 1). The four sampling sites (the upper courses of the Centuria, Wiercica, and Vistula and the lower course of the Korzenica River) are located within the protected areas of nature reserves and Natura 2000, whereas the sampling sites of the Mleczna and Bolina rivers are located within the most urbanised and industrialised parts of the USCB.

\subsection{Environmental Surveys}

Prior to the macroinvertebrate sampling, water samples and bottom sediments were collected from each sampling site. The physical and chemical parameters of the water, i.e. $\mathrm{pH}$, temperature and the concentration of oxygen were measured in the field using CO-401 Elmetron and HI-9811-5 Hanna Instruments portable meters. The concentrations of nutrients, iron, chlorides, sulphates, alkalinity, magnesium, calcium and total hardness were analysed in the laboratory. The concentration of ammonium (Nessler method); nitrites 
(adaptation of the EPA diazotization method 354.1.); nitrates (cadmium reduction method); phosphates (adaptation of the ascorbic acid method); iron (phenanthroline method); sulphates (turbidimetric method); calcium (adaptation of the oxalate method); magnesium (adaptation of the calmagite method) in the water and hardness (adaptation of the EPA method 130.1.) were determined using Hanna Instruments (USA) reagents and portable photometers. The concentration of chlorides was analysed according to the titrimetric determination with a mercury nitrate solution (mercurimetric determination against 1.5 diphenylcarbazone) and alkalinity according to the acidimetric titration against phenolphthalein or mixed indicator using Merck reagents.

Electrical conductivity (EC) and total dissolved solids (TDS) were measured in the field using a Multi 3410 WTW meter and the results were converted to the salinity according to Piscart et al. (2005). The width, depth and flow velocity of the rivers were measured in the field (Hauer and Lamberti 2007). The organic matter content $(\%)$ in the bottom sediments was determined according to the methods of Myślińska (2001). The grain size composition of the bottom sediments was determined using both the sieve and aerometric methods.

The anthropogenic pressure on the watercourses and adjacent land use was assessed in accordance with the field survey method, i.e. the Hydromorphological Index for Rivers (HIR) and the calculation of two numerical metrics, i.e. the Hydromorphological Diversity Index (WRH) and the Hydromorphological Transformation Index (WPH) (Szoszkiewicz et al. 2017, 2020). The HIR method, which was prepared mainly on the basis of the British River Habitat Survey (RHS), was adapted to Polish conditions (Szoszkiewicz et al. 2017, 2020). These studies included both fieldwork and analyses of the Geographic Information Systems data and remote sensing materials. High values of the WRH and HIR indices reflect a large number of the natural characteristics of rivers and the adjacent land use, while a high value of the WPH reflects strong anthropopressure on a river and the adjacent land use.

The macroinvertebrate samples were collected using a quadrat frame and hydrobiological net with a $0.4-\mathrm{mm}$ mesh sieve from different microhabitats (bottom sediments and macrophytes) according to the standard

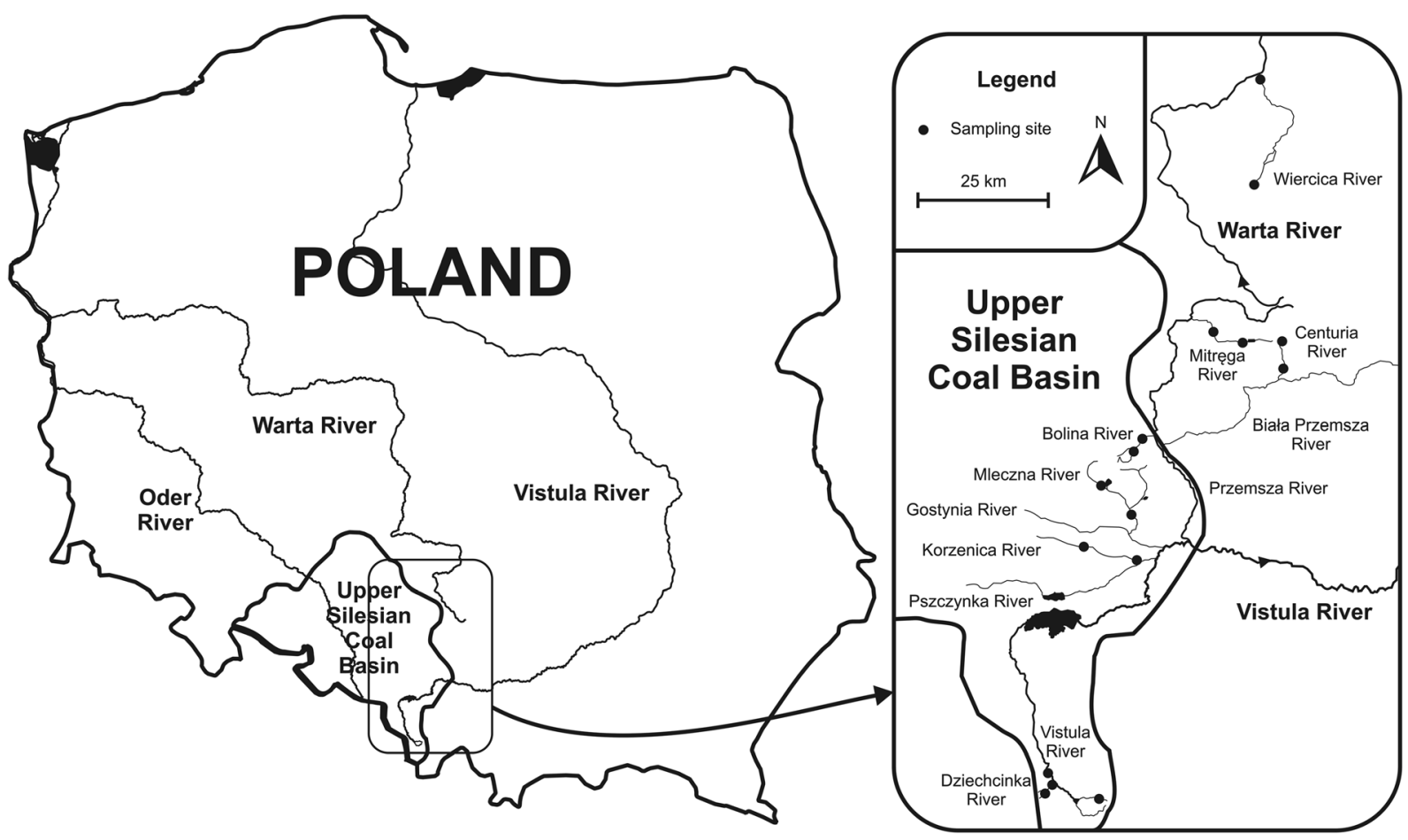

Fig. 1 Study area and sampling sites 


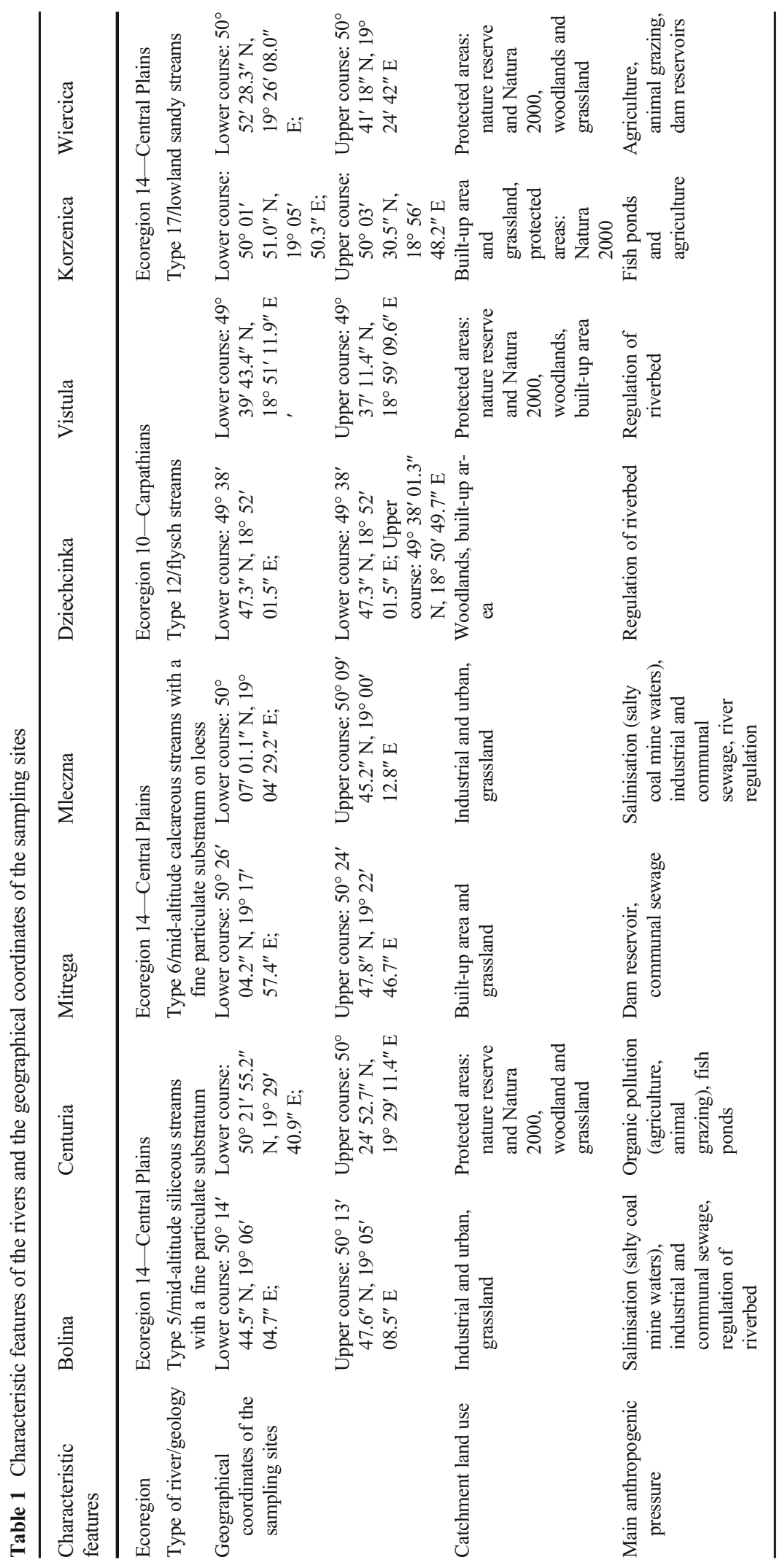


methods. A total of 367 biological samples were collected from different types of microhabitats. The samples were sorted and preserved in $80 \%$ ethanol. The collected material was identified to the lowest possible level according to Rozkošný (1980), Kołodziejczyk and Koperski (2000), Eggers and Martens (2001), Tończyk et al. (2013), Piechocki and Wawrzyniak-Wydrowska (2016), Mauch (2017) and Rudolph et al. (2018) and counted under a stereoscopic microscope (OLYMPUS SZ61 SZ2-ILST). The wet weight of the macroinvertebrates was measured on a laboratory balance with an accuracy of $0.001 \mathrm{~g}$ after removing excess water by drying the macroinvertebrates on filter paper. The density and biomass of the macroinvertebrates was estimated as the number of individuals per square metre and gramme $(\mathrm{g})$, respectively.

\subsection{Statistical and Zoocenological Analyses}

The zoocenological analysis of the macroinvertebrate communities was based on the Shannon-Wiener index $H^{\prime}$ (Hauer and Lamberti 2007).

The significance of the differences in the median values of the environmental variables, the number of taxa, the density and biomass of macroinvertebrates and the values of the Shannon-Wiener index $H^{\prime}$ between the rivers was calculated using the Kruskal-Wallis one-way ANOVA and Dunn's multiple comparison post hoc tests. The values of the biological data and environmental variables did not reveal a normal distribution according to the Lilliefors test of normality, which justified the use of a non-parametric test. The statistical analyses were performed using Statistica version 13.1.

Canonical ordination analyses for relating the taxonomic composition of macroinvertebrates to the environmental variables were performed using CANOCO for Windows version 4.5 (Ter Braak and Smilauer 2002). The appropriate type of analysis was selected to analyse the biological data using detrended correspondence analysis (DCA) and the length of the gradient. The gradient length exceeded 3 SD (the standard deviation), therefore a unimodal direct ordination, canonical correspondence analysis (CCA) with a forward selection was used to reduce the large set of environmental variables (a maximum gradient length of 5.161). The following environmental variables were included in the CANOCO analysis: the physical and chemical parameters of the water, altitude, stream gradient, the width, depth and flow velocity of the rivers, the area of catchments, the grain size composition of the bottom sediments, the organic matter content in the bottom sediments and the values of the hydromorphological indices. Macroinvertebrate taxa that occurred at fewer than 10\% of the sampling sites were excluded from the statistical analyses following a preliminary exploration of their influence in the initial DCA analysis (McCune and Grace 2002). Both the biological and environmental data were log-transformed. The statistical significance of the relationship between the biological data and the environmental variables was evaluated using the Monte Carlo permutation test (499 permutations) (Ter Braak and Smilauer 2002).

\section{Results}

The values of the WRH, which reflect the number and abundance of the natural features of the rivers and the adjacent land use, were relatively high (up to 88.5) for the sampling sites that are located within the protected areas: the nature reserves and Natura 2000 (the upper courses of the Vistula and Wiercica rivers) (Table 2). The relatively high values of the WPH reflected a high degree of the anthropogenic modification of the habitats and were recorded for the river sections within the city located outside the most urbanised and industrialised parts of the USCB (abiotic type 12: the Dziechcinka and Vistula rivers) (Table 2). Total hardness, alkalinity, the concentration of nutrients, calcium, magnesium, salinity and the parameters associated with salinity, i.e. EC, TDS, the concentrations of chlorides and sulphates were very high for the sampling sites located in the most urbanised and industrialised parts of the USCB (the Bolina and Mleczna rivers) compared with the sampling site located outside of the USCB and the protected areas (Table 3).

The differences in the median values of most of the physical and chemical parameters of the water and the morphological features between the rivers were significant $(p<0.01)$ (the Kruskal-Wallis one-way ANOVA and multiple comparison post hoc tests) (Tables 2 and 3 and Appendix Table 4). The Kruskal-Wallis one-way ANOVA and the multiple comparison post hoc tests test revealed statistically significant differences $(p<0.05)$ in the median number of taxa, density and the median values of the Shannon-Wiener index $H^{\prime}$ between the rivers (Fig. 2). 


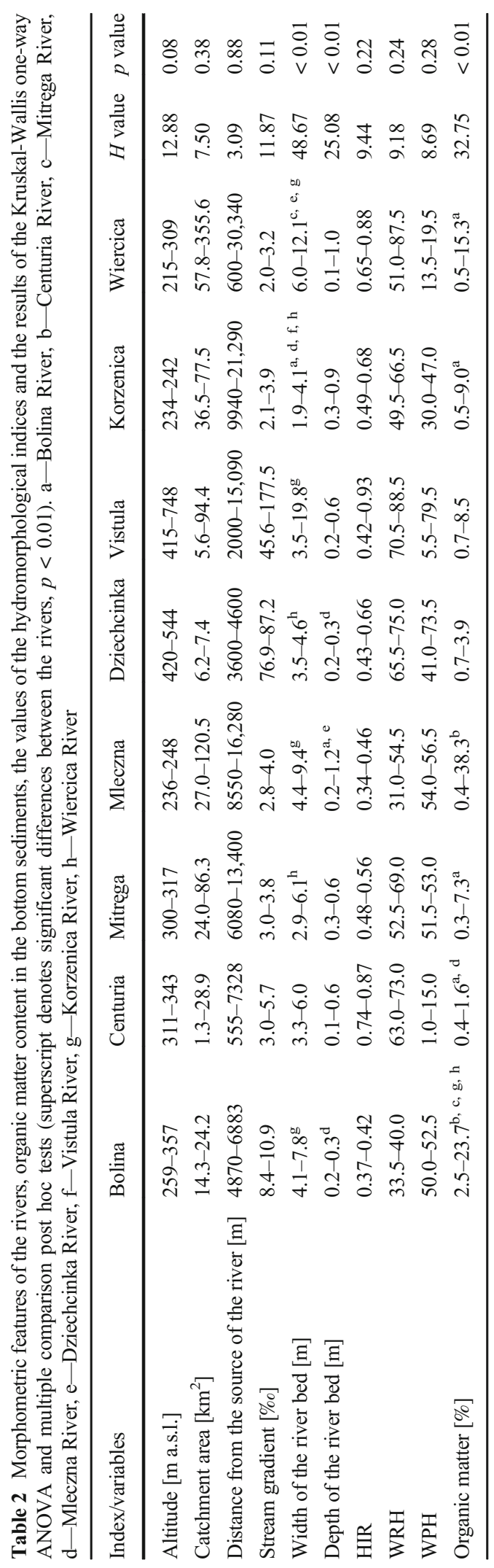




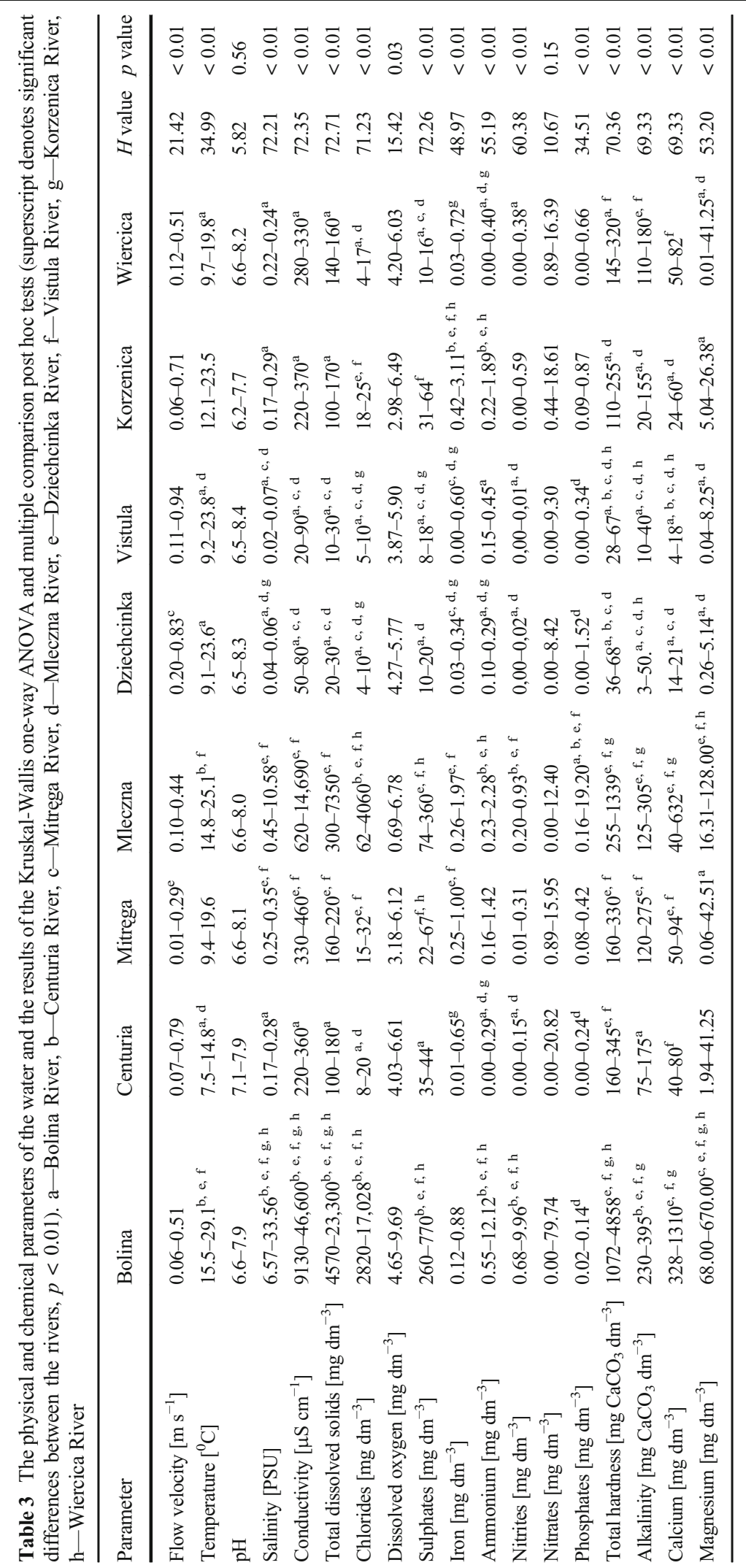


The Shannon-Wiener index $H^{\prime}$ summarises the species richness, evenness and the density of the taxa in samples including rare and not numerous species. Therefore, higher median values of $H$ ' were recorded for the rivers with a higher number of the natural features and the adjacent land use, which was reflected by the maximum values of the WRH (less human-impacted rivers) (Fig. 2). A higher median number of taxa and values of the $H^{\prime}$ index were recorded for the less humanimpacted rivers within the same abiotic types, i.e. for the Centuria River within abiotic type 5, for the Mitrega River within abiotic type 6 , for the Vistula River within abiotic type 12 and for the Wiercica River within abiotic type 17 (Fig. 2). The lowest median number of taxa and values of the Shannon-Wiener index $H^{\prime}$ were obtained

a

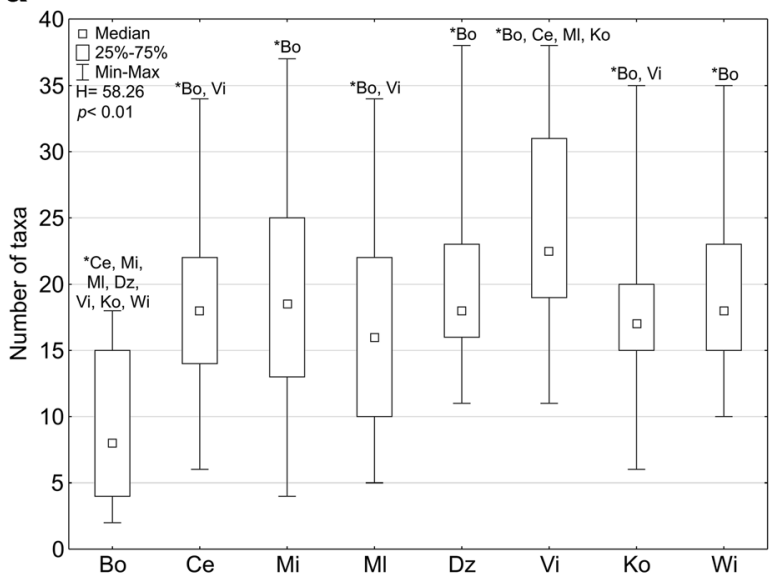

c

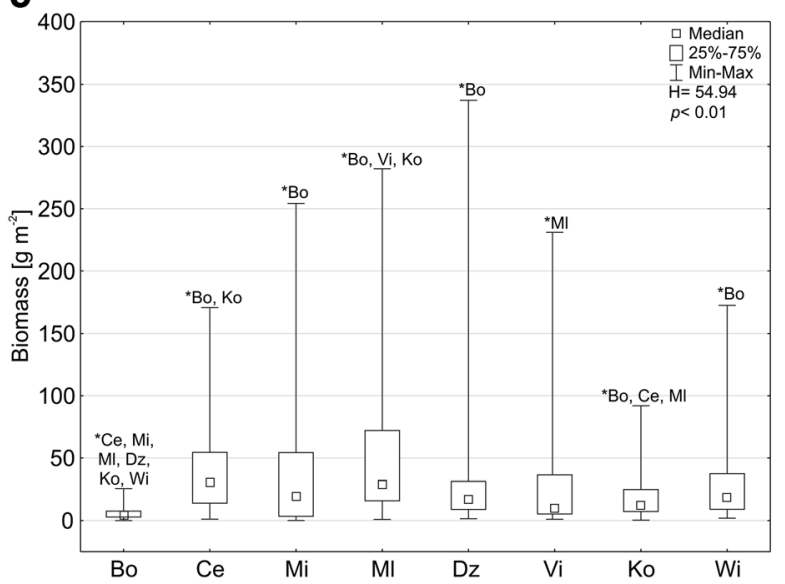

Fig. 2 Box-and-whisker plot showing the a number of taxa, $\mathbf{b}$ density, $\mathbf{c}$ biomass of the macroinvertebrates and $\mathbf{d}$ values of the Shannon-Wiener index $H^{\prime}$ in the rivers (asterisks above a whisker denote significant differences between the rivers, $p<0.01$ ). for the most salinised rivers, i.e. for the Bolina and Mleczna rivers, even though the maximum density of macroinvertebrates was relatively high in the Mleczna caused by invasive alien species (Fig. 2).

A total 143 macroinvertebrate taxa were recorded in the studied rivers (Appendix Table 5). The number of macroinvertebrate taxa ranged from 40 in the Bolina River to 99 in the Wiercica River. Among them, three invasive alien species were recorded, i.e. Gammarus tigrinus (in the lower course of the Bolina River and in the Mleczna River), Potamopyrgus antipodarum (in the upper course of the Bolina River and in the Mleczna River), Orconectes limosus (in the lower courses of the Korzenica and Wiercica rivers), two alien gastropod species, i.e. Ferrissia fragilis (in the upper course of b

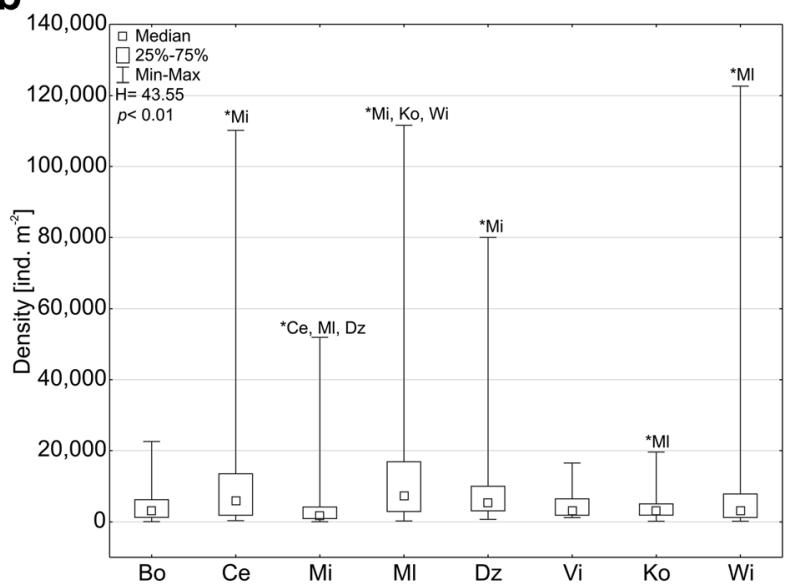

d

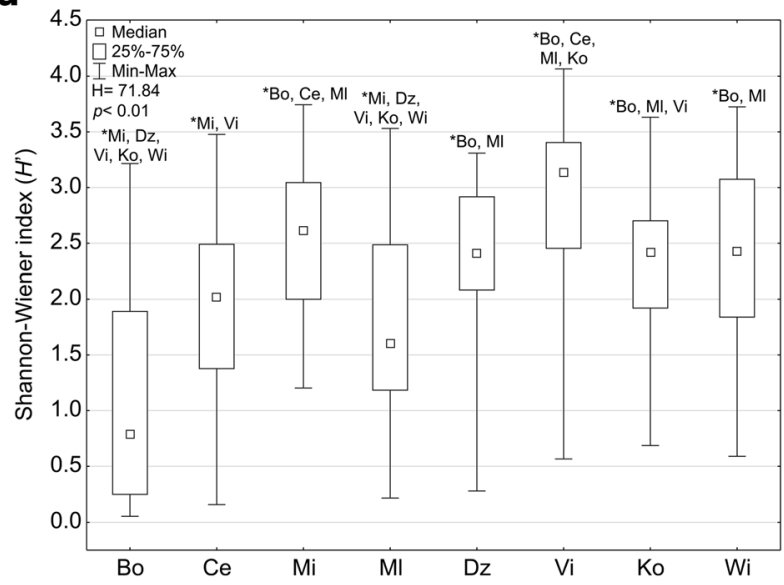

Bo-Bolina River, Ce-Centuria River, Mi-Mitręga River, Ml-Mleczna River, Dz-Dziechcinka River, Vi-Vistula River, Ko-Korzenica River, Wi-Wiercica River 
the Korzenica River) and Physa acuta (in the Mleczna River). One species of unionid mussel, i.e. Anodonta anatina, which made up a small percentage in the macroinvertebrate communities, only occurred in the rivers of abiotic type 6 (the Mitrega, the upper course of the Mleczna).

Canonical correspondence analysis (CCA) based on the macroinvertebrate data and environmental variables showed that the first two axes explained $17.4 \%$ of the variance in the biological data and $71.8 \%$ of the variance in the biological data and environment relationships. The results of CCA proved that many environmental factors affect the occurrence of macroinvertebrates simultaneously. In addition to the physical and chemical parameters of the water, the geographical and habitat factors as well as the hydromorphological parameters of rivers were also important. Selection of the environmental variables based on the forward selection (FS) results and the marginal and conditional effects showed that $\mathrm{EC}$, altitude, the values of the WRH, hardness, medium sand (particles of $0.5-0.25 \mathrm{~mm}$ ), pebble (particles above $20 \mathrm{~mm}$ ) and the organic matter content in the bottom sediments were the parameters most associated (statistically significant, $p=0.002$ ) with the distribution of the macroinvertebrates (Fig. 3). According to the forward selection, among the environmental factors, EC had the strongest effect on the distribution of the macroinvertebrates including the invasive alien species. The anthropogenic salinisation of the Mleczna and Bolina rivers of up to $33.6 \mathrm{PSU}$ (23 $300 \mathrm{mg} \mathrm{dm}^{-3}$ TDS, salinity similar to the North Sea) negatively impacted the macroinvertebrate communities directly. Gastropod Ancylus fluviatilis and Bythinella sp., the crustacean Gammarus fossarum, dipterans (Blephariceridae, Dixidae, Athericidae) and most of ephemeropteran, plecopteran and trichopteran taxa (e.g. Odontocera albicorne, Glossosomatidae, Odontoceridae, Polycentropodidae, Sericostomatidae, Rhyacophilidae, Perlidae, Perlodidae, Nemouridae, Heptageniidae, Leuctridae) were affected by altitude and the natural features of the rivers, which was reflected by the values of the WRH and pebbles (Fig. 3). Gammarus jazdzewskii, Leptophlebiidae, Limnephilidae, Polycentropodidae, Pisidium sp., Sphaerium sp. and Leptoceridae were the taxa positively correlated with an increasing value of the WRH or by both the values of the WRH and medium sand. The abundance of gastropods (e.g. Bithynia tentaculata, Planorbarius corneus, Gyraulus crista and Radix balthica) was associated with the hardness and a lower altitude, whereas the abundance of Oligochaeta, Chironomidae or Tabanidae was associated with the organic matter content in the bottom sediments. The brackish and marine invasive alien species, i.e. Gammarus tigrinus, Potamopyrgus antipodarum and the alien gastropod Physa acuta occurred at the sampling sites with a higher EC. The relationship between the taxonomic composition of the macroinvertebrates and the environmental variables was statistically significant (Monte Carlo test of significance of the first canonical axis: $p=0.002, F$-ratio $=44.88$; test of significance of all of the canonical axes: $p=0.002, F$-ratio $=$ 16.42).

\section{Discussion}

This study proved that the physical, chemical and hydromorphological anthropogenic transformations are important in explaining the distribution of macroinvertebrates in human-impacted Central European rivers. Our results, which showed a decrease in macroinvertebrate biodiversity in the most salinised rivers reflected by the lowest median values of the Shannon-Wiener index $H^{\prime}$ for the macroinvertebrate communities, are consistent with numerous studies that have been carried out in secondary saline rivers worldwide (Battaglia et al. 2005; Piscart et al. 2005; Bäthe and Coring 2011; Arle and Wagner 2013; Cañedo-Argüelles et al. 2013, 2017; Ladrera et al. 2017). According to Pinder et al. (2005), the threshold value of salinity is $4100 \mathrm{mg} \mathrm{dm}^{-3} \mathrm{TDS}$, above which the biodiversity begins to decrease. Even a small increase in salinity up to about $800 \mathrm{mg} \mathrm{dm}^{-3}$ TDS inhibits macroinvertebrate reproduction and reduces their growth, while at a salinity of approximately $9000 \mathrm{mg} \mathrm{dm}^{-3} \mathrm{TDS}$, their osmoregulatory functions begin to fail (Hart et al. 1991; James et al. 2003). The juvenile forms of these organisms (e.g. larvae such as glochidia) are generally more sensitive to salinity and their occurrence is limited to the maximum ranges of salinity tolerance for adult macroinvertebrates (Hart et al. 1991; Blakeslee et al. 2013; Herbert et al. 2015; Lopes-Lima et al. 2017). Nevertheless, a slight increase in EC to $300-500 \mu \mathrm{S} \mathrm{cm}^{-1}$ may increase species richness substantially (Kefford et al. 2011). The salinity gradient that was obtained in our survey proves that with increasing EC, salinity-sensitive taxa are replaced by eurytopic and euryhaline taxa including invasive 
alien species. The brackish and marine amphipodGammarus tigrinus is an example of such a species which, among others, because of the saltwater pollution of rivers, has had colonisation success in Europe and is still expanding its range (Lewin et al. 2018; Rewicz et al. 2019).

An increase in the concentration of salts in rivers induces physiological stress, and ultimately, can cause major changes in the macroinvertebrate communities and the functions of the ecosystem. For example, water with an EC higher than $1500 \mu \mathrm{S} \mathrm{cm}^{-1}$ is not suitable for irrigating most crops and extirpates many species of freshwater invertebrates, while water of EC of 2500 $\mu \mathrm{S} \mathrm{cm}{ }^{-1}$, according to standards established in some countries, is not suitable for drinking or for use in some areas of industry (Cañedo-Argüelles et al. 2013, 2016). Freshwater mussels are sensitive to increasing salinity, whose values higher than $1400 \mu \mathrm{S} \mathrm{cm}^{-1}$ may negatively affect their metabolic processes and cause mortality (Blakeslee et al. 2013). As a consequence, rivers with an elevated salinity lose their ecosystem services. Our results revealed that highly saline rivers, e.g. the Bolina River and the lower course of the Mleczna River were devoid of mussels. Hence, the anthropogenic salinity of waters has a substantial impact not only on freshwater biota, but also on the goods and services that rivers provide to people, and therefore, they can be associated with high economic costs (Cañedo-Argüelles et al. 2013, 2016). In addition, rivers with the discharge of underground salty mine waters can cause local

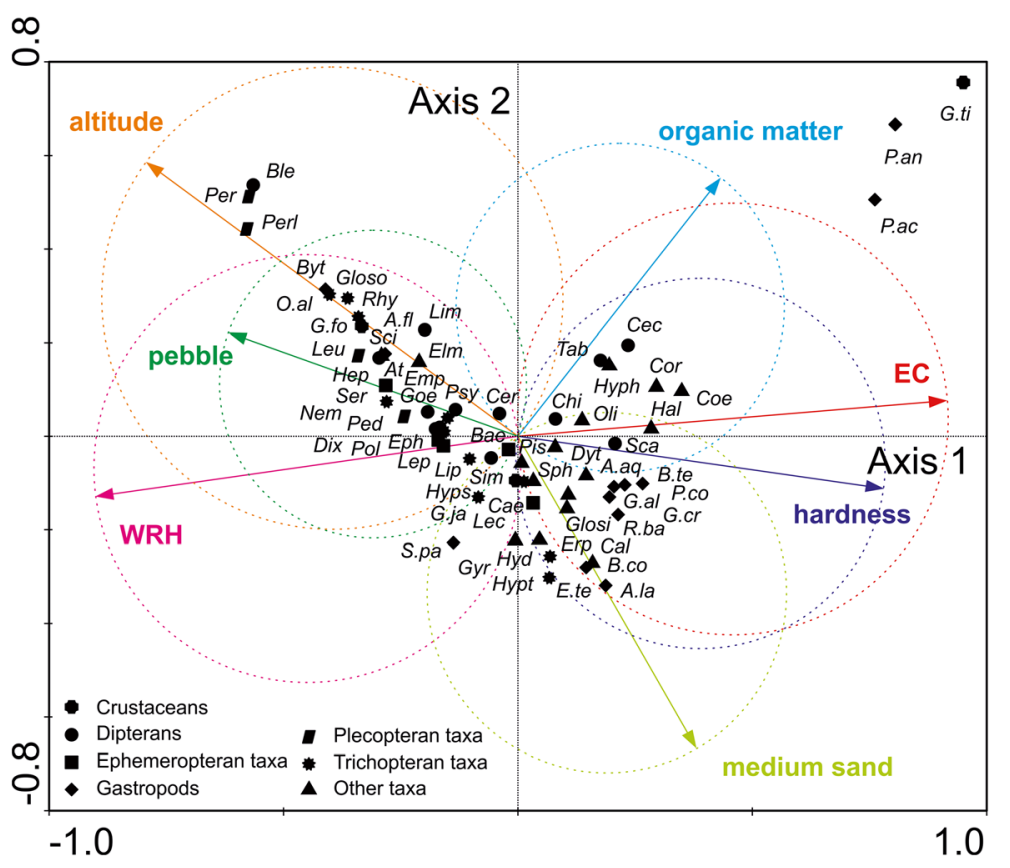

Fig. 3 Ordination diagram (biplot) based on the canonical correspondence analysis (CCA) of the macroinvertebrate taxa and selected environmental variables. Van Dobben circles indicate a positive relationship between the macroinvertebrate taxa and specific environmental variables. A.la-Acroloxus lacustris, A.fl-Ancylus fluviatilis, A.aq-Asellus aquaticus, At-Athericidae, Bae-Baetidae, B.co-Bathyomphalus contortus, B.te-Bithynia tentaculata, Ble-Blephariceridae, Byt-Bythinella sp., Cae-Caenidae, Cal-Calopterygidae, Cec-Cecidomyidae, Cer-Ceratopogonidae, Chi-Chironomidae, Coe-Coenagrionidae, Cor-Corixidae, Dix-Dixidae, Dyt-Dytiscidae, E.te-Ecnomus tenellus, Elm-Elmidae, Emp-Empididae, Eph-Ephemerellidae, Erp-Erpobdellidae, G.fo-Gammarus fossarum, G.ja-Gammarus jazdzewskii, G.ti-Gammarus tigrinus,

Glosi-Glossiphoniidae, Gloso-Glossosomatidae, Goe-Goeridae, G.al-Gyraulus albus, G.cr-Gyraulus crista, Gyr-Gyrinidae, Hal-Haliplidae, Hep-Heptageniidae, Hyph-Hydrophilidae, Hyps-Hydropsychidae, Hypt-Hydrptilidae, Hyd-Hydrozoa, Lec-Leptoceridae, Lep-Leptophlebiidae, Leu-Leuctridae, Lip-Limnephilidae, Lim-Limoniidae, Nem-Nemouridae, O.al-Odontocera albicorne, Oli-Oligochaeta, Ped-Pediciidae, Per-Perlidae, Perl-Perlodidae, P.ac-Physa acuta, Pis-Pisidium sp., P.co-Planorbarius corneus, Pol-Polycentropodidae, P.an-Potamopyrgus antipodarum, Psy-Psychodidae, R.ba-Radix balthica, Rhy-Rhacophilidae, Sca-Scatophagidae, Sci-Scirtidae, Ser-Sericostomatidae, Sim-Simuliidae, Sph-Sphaerium sp., S.pa-Stagnicola palustris, Tab-Tabanidae 
environmental contamination due to excessive salt loads as well as heavy metals and sometimes radioactive substances (Harat and Grmela 2008).

The anthropogenic salinisation of rivers (especially the strong salinity that is associated with the discharge of salty mine waters, but also with the agents that are used to de-ice roads) and its impact on freshwater biota illustrates the consequences of climate change. The consequences of climate change will not only increase the number of violent phenomena and change the volume and time of precipitations, but will also result in an increase in the average annual temperatures and droughts, which may contribute to an increasing salt concentration in freshwater environments (Nijssen et al. 2001; Fischer et al., 2007; Neubauer and Craft 2009; Herbert et al. 2015; Cañedo-Argüelles et al. 2016; Maxwell et al. 2016; Berger et al. 2019). Therefore, rivers that have been polluted with salty mine waters, e.g. the Bolina, the Gostynia, the Mleczna and the Soldevila rivers (Ladrera et al. 2017; Lewin et al. 2018; Halabowski et al. 2020) may constitute an appropriate model for research on the impact of climate change on freshwater organisms in Europe. Our results showed that among the rivers that are impacted by the discharge of hard coal mine waters, the Bolina River is currently the most salinised river in the world. Undoubtedly, comprehensive guidelines are required for monitoring, regulating, managing and dealing with the salinity of freshwater (Schuler et al. 2019). However, in order to prevent or limit climate change, a rapid reduction of coal mining is necessary and the use of energy from this source should be discontinued. This is particularly important in a country such as Poland, which was responsible for producing 61.6 million tonnes of hard coal in 2019, which accounted for 95\% of the total production in the European Union (Eurostat Statistics Explained 2020). The output and processing of hard coal affects both the anthropogenic salinisation of inland water and climate change. Hard coal, which is a natural resource, is extracted from the underground seams and then to the earth's surface throughout the world. Poland hosts the largest number of coal mines (35) followed by Spain, Germany and Bulgaria (Alves Dias et al. 2018). According to McGinley (2011), annual world coal production is projected to grow to seven billion tonnes by 2030, and China will account for half of the increase. Poland is in the 10th largest world coal consumer. The enormous consumption of billions of tonnes of coal for generating electricity pollutes the
Earth's atmosphere with greenhouse gases including $\mathrm{SO}_{2}, \mathrm{CO}_{2}, \mathrm{NO}_{x}$ and ozone (McGinley 2011). Coal contributes more climate change-inducing greenhouse gases than any other fossil fuel. In the USCB, the extraction of hard coal that is sent to the earth's surface requires that underground mine waters, which carry high concentrations of salts, mainly chlorides and sulphates and also heavy metals and radionuclides, be pumped out. In order for the underground mine waters not to flood the mine workings, they are pumped out to the surface through mine dewatering systems and are initially discharged into central settling ponds and then directed to surface waters (waterbodies) or directly to the rivers (Strozik 2017; Halabowski et al. 2019). Therefore, the rivers of the Vistula and Oder catchments are strongly affected by the highly mineralised coal mine waters originating from the dewatering systems of hard coal mines. This result showed that among the rivers that are impacted by the discharge of hard coal mine waters, the Bolina River is currently the most salinised river in the world. The Bolina River is an example of a saline tributary of the upper Vistula River (Halabowski and Lewin 2020). Moreover, the increase in the consumption of hard coal means that it has to be extracted from deeper layers of the earth. The deeper the hard coal seams that are exploited, the more saline waters occur in underground layers that are then pumped out to the surface watercourses of the USCB. What is more, even if hard coal mines are closed for economic reasons, pumping out salty mine waters to the surface is continued so that these waters do not flood the mine workings and adjacent areas. Although the output of hard coal has decreased in the USCB, the discharge of saline waters ( 325 thousand $\mathrm{m}^{3}$ per day) and the load of salts (355 tonnes per day) from hard coal mines has not followed this trend (Strozik 2017). All mine waters with an average salt concentration of about $10 \mathrm{~kg} \mathrm{~m}^{-3}$ are discharged into the tributaries of the catchments of the Vistula and Oder including the Bolina and the Mleczna and then affect river biota.

The transformations of flowing waters that are caused by regulating rivers, constructing dams and other hydrotechnical devices and intentionally or accidentally introducing alien species as well as climate change all negatively affect the biota and natural abiotic elements of rivers (Allan and Castillo 2009; Herbert et al. 2015). It also intensifies the effects of salinity. Population growth (which involves an intensification of agriculture) and climate change will certainly intensify this problem 
(Vörösmarty et al. 2000). Therefore, it has become necessary to determine the degree of the hydromorphological changes and to measure them using the indices for determining the quality of river habitats. Our research showed that the natural features of rivers and the adjacent land use, which are reflected by the values of the WRH, were the most important factors that affected the distribution of macroinvertebrates in the rivers. Both the most anthropogenically transformed rivers and eurytopic taxa were negatively associated with the WRH. Several other studies (Hering et al. 2006; Lewin et al. 2013, 2014; Paller et al. 2014; Lewin et al. 2015) have reported similar correlations. Our survey revealed the relatively high values of the WPH reflected a high degree of the anthropogenic modification of the habitat for the river sections of the Dziechcinka and Vistula (flysch streams) within the city located outside the most urbanised and industrialised parts of the USCB. This surprising pattern may be explained by the location of these sections of the rivers in the centre of the Wisła city (famous sports and recreational resort with high volumes of tourist traffic in the Beskid Ślaski Mts.). Strong water flow and quick increase in the water level during a rainfall in these sections determined heavily transformation of the riverbeds (regulation, concrete reinforcement of the bank) and land use to protect the city from flooding. Therefore, higher values of the WPH were recorded for these sampling sites than for other sampling sites. However, despite the fact that the substantial impact of hydromorphological transformation (number and abundance of the natural features of the rivers and the adjacent land use) that has been determined using the appropriate indices has been proven, these environmental variables are still not taken into account by researchers that are trying to explain the occurrence of macroinvertebrates in watercourses, especially in human-impacted rivers. In our research, salinity and altitude proved to be more decisive for the occurrence of macroinvertebrates in the rivers. This is justified in the light of the above arguments as an effect of secondary salinisation on freshwater macroinvertebrates, while altitude, which reflects geology, is mentioned as a very important factor that is associated with the structure of the benthic macroinvertebrate communities in rivers (Rawer-Jost et al. 2004; Šporka et al. 2009; Lewin et al. 2013, 2014).

These surveys found a relatively high content of organic matter in bottom sediments at the sampling sites that were located at different distances below dam reservoirs. In addition, some sampling sites were located within agricultural areas. According to the results of the CCA, some macroinvertebrate taxa were affected by the organic matter content in the bottom sediments. This finding confirmed that the occurrence of eurytopic species is positively correlated with a high organic matter content in the bottom sediments (Allan and Castillo 2009; Ward et al. 2002). What is more, our results also showed that the extremely high organic matter content in the bottom sediments consisted mainly of mining waste in the rivers into which there was a discharge of hard coal mine waters. This phenomenon can be explained by the increased sedimentation in saltwater and the flocculation of sediment that is caused by the divalent cations in saline water (e.g. $\mathrm{Ca}^{2+}$ and $\mathrm{Mg}^{2+}$ ) because of the aggregation of suspended matter (Sholkovitz 1976; Grace et al. 1997; Meiggs and Taillefert 2011; de Nijs and Pietrzak 2012). This is consistent with our results, because in both the Bolina and Mleczna rivers, high concentrations of calcium, magnesium and total hardness were recorded, and those higher values significantly ( $p=0.002)$ affected the occurrence of eurytopic macroinvertebrate taxa.

\section{Conclusions}

Our results showed the crucial role both of the physical, chemical and hydromorphological anthropogenic transformations in explaining the gradient in the distribution of macroinvertebrates in the studied rivers, which are under different degrees of human impact. In contrast to the assumed hypothesis, these results proved that the hydromorphological transformation of human-impacted Central European watercourses, which is expressed by the relevant indices and is often overlooked or underestimated by scientists, is one of the most predictive factors that contribute to the distribution of macroinvertebrates including invasive alien species. The application of the HIR methods and the calculation of two indices, i.e. the WRH and WPH enabled the impact of human pressure to be assessed. Our results also showed that both the WRH and WPH indices are indispensable tools for assessing the degree of human pressure within the catchment area of the human-impacted Central European rivers. The WRH not only reflected the degrees of the natural features of a riverbed and the land use adjacent to a river but also the relationships between 
the habitat features and the structure of the macroinvertebrate communities. Therefore, in future surveys, we recommend that the Hydromorphological Diversity Index be applied and that the hydromorphological status of rivers based on the HIR methods be considered to be drivers that determine the structure of the macroinvertebrate communities in rivers. Our survey revealed that anthropogenic salinity and the hydromorphological transformations of river habitats reflect a high level of human pressure, which triggers the occurrence and spread of the alien gastropod Physa acuta and brackish and marine invasive alien species including Gammarus tigrinus and Potamopyrgus antipodarum. We can conclude that the anthropogenic salinised inland waters due to the discharge of hard coal mine waters create new habitats for brackish and marine species that replace the native freshwater species. Moreover, these salty habitats can illustrate future changes that are connected with an increase in the human population and climate change and can be used to model the impact of these changes on freshwater biota. In addition, rivers impacted by salty mine waters discharge lose their ecosystem service indirectly (e.g. unionid mussels, which are effective filtrators, are unable to support the process of selfpurification of waters) and therefore such waters are not suitable for human use. Among the rivers that are impacted by the discharge of hard coal mine waters, the Bolina River, which is currently the most salinised river in the world, is an example of such a watercourse. However, all possible actions should be taken to minimise the anthropogenic salinity of inland waters including implementing comprehensive legal regulations.

Acknowledgements The authors are grateful to the Editor-inChief and the anonymous reviewers for their valuable suggestions and comments on this manuscript and to Ms. Michele L. Simmons, B.A., the University of Silesia, Katowice, Poland, for improving the English style.

Funding This research was funded by University of Silesia in Katowice (Institute of Biology, Biotechnology and Environmental Protection) and partially supported by the Polish Ministry of Science and Higher Education Funding for Statutory Activities (Young Scientists 2018 grant). Dariusz Halabowski was supported by the Scholarship of the Polish National Agency for Academic Exchange (NAWA) at PROM Programme (project no POWR.03.03.00-00PN13/18).Data AvailabilityData will be available on request.

\section{Declarations}

Conflict of Interest The authors declare no competing interests. 


\section{Appendix 1}

Table 5 The percentage share of specific taxa (\%) in the macroinvertebrate communities in the studied rivers

\begin{tabular}{|c|c|c|c|c|c|c|c|c|}
\hline Taxon & Bolina & Centuria & Mitręga & Mleczna & Dziechcinka & Vistula & Korzenica & Wiercica \\
\hline \multicolumn{9}{|l|}{ Arachnida } \\
\hline Argyroneta aquatica (Clerck, 1757) & 0.082 & 0.018 & 0.060 & 0.040 & 0.024 & 0.023 & 0.014 & 0.086 \\
\hline \multicolumn{9}{|l|}{ Malacostraca } \\
\hline Asellus aquaticus (Linnaeus, 1758) & - & 0.372 & 1.157 & 6.878 & - & 0.003 & 12.250 & 1.997 \\
\hline Gammarus fossarum Koch, 1836 & - & - & - & - & 32.820 & 8.922 & - & - \\
\hline $\begin{array}{l}\text { Gammarus jazdzewskii Rudolph, } \\
\text { Coleman, Mamos \& Grabowski, } 2018\end{array}$ & - & 7.592 & 2.046 & - & - & - & - & 9.488 \\
\hline Gammarus tigrinus Sexton, 1939 & 0.458 & - & - & 23.166 & - & - & - & - \\
\hline Orconectes limosus (Rafinesque, 1817) & - & - & - & - & - & - & 0.001 & 0.002 \\
\hline \multicolumn{9}{|l|}{ Collembola } \\
\hline Isotomidae & 0.007 & 0.008 & 0.026 & 0.042 & 0.092 & 0.061 & 0.010 & 0.110 \\
\hline Podura aquatica Linnaeus, 1758 & - & - & 0.002 & 0.003 & 0.006 & - & 0.014 & 0.006 \\
\hline Poduridae & - & 0.001 & - & 0.015 & 0.002 & 0.012 & - & - \\
\hline \multicolumn{9}{|l|}{ Coleoptera } \\
\hline Chrysomelidae & - & - & 0.017 & 0.001 & - & - & 0.006 & 0.002 \\
\hline Curculionidae & 0.007 & - & 0.008 & 0.002 & - & - & 0.008 & 0.011 \\
\hline Dytiscidae & 0.137 & 0.057 & 0.245 & 0.005 & 0.015 & 0.429 & 1.025 & 0.093 \\
\hline Elmidae & 0.020 & 0.099 & 3.357 & 0.006 & 9.928 & 11.754 & 4.413 & 0.094 \\
\hline Eubria palustris Germar, 1818 & - & - & - & - & - & 0.020 & - & 0.001 \\
\hline Gyrinidae & - & 0.007 & 0.015 & - & 0.007 & 0.138 & 0.407 & 0.028 \\
\hline Haliplidae & 0.180 & 0.005 & 0.328 & 1.189 & - & 0.006 & 0.840 & 0.004 \\
\hline Helophoridae & - & - & 0.002 & 0.001 & - & 0.003 & - & 0.003 \\
\hline Hydraenidae & - & 0.001 & 0.009 & - & 0.097 & 0.181 & - & 0.013 \\
\hline Hydrochidae & - & - & - & - & 0.002 & - & - & - \\
\hline Hydrophilidae & 0.892 & 0.008 & 0.226 & 0.026 & 0.014 & 0.026 & 0.025 & 0.023 \\
\hline Scirtidae & 0.003 & 0.023 & 0.091 & 0.004 & 0.575 & 1.641 & 0.010 & 0.333 \\
\hline \multicolumn{9}{|l|}{ Diptera } \\
\hline Athericidae & - & 0.011 & - & - & 0.006 & 0.043 & 0.004 & 0.004 \\
\hline Blephariceridae & - & - & - & - & 0.009 & 0.144 & - & - \\
\hline Cecidomyidae & 1.775 & 0.004 & 0.030 & 0.003 & 0.020 & 0.009 & 0.029 & 0.004 \\
\hline Ceratopogonidae & 0.275 & 0.109 & 0.594 & 0.061 & 0.283 & 0.320 & 0.095 & 0.229 \\
\hline Chironomidae & 61.517 & 15.969 & 24.531 & 14.094 & 17.951 & 30.450 & 37.274 & 48.099 \\
\hline Culicidae & 0.010 & - & - & 0.001 & 0.002 & - & 0.025 & 0.013 \\
\hline Dixidae & - & 0.066 & 0.087 & - & 0.013 & 0.510 & 0.006 & 0.087 \\
\hline Dolichopodidae & 0.654 & 0.001 & - & 0.001 & - & - & - & - \\
\hline Empididae & 0.616 & 0.046 & 0.019 & 0.005 & 0.338 & 0.570 & 0.008 & 0.276 \\
\hline Ephydridae & 0.010 & 0.001 & - & 0.007 & 0.005 & - & - & 0.007 \\
\hline Fannidae & - & - & - & 0.003 & 0.003 & 0.003 & - & - \\
\hline Limoniidae & 0.036 & 0.004 & 0.011 & 0.001 & 0.070 & 0.233 & 0.020 & 0.032 \\
\hline Muscidae & 0.003 & 0.001 & 0.026 & 0.001 & 0.090 & - & - & - \\
\hline Pediciidae & - & 0.032 & 0.064 & - & 0.018 & 0.308 & 0.173 & 0.041 \\
\hline Psychodidae & 0.177 & 0.034 & 0.100 & - & 0.934 & 2.070 & 0.003 & 1.786 \\
\hline
\end{tabular}


Table 5 (continued)

\begin{tabular}{|c|c|c|c|c|c|c|c|c|}
\hline Taxon & Bolina & Centuria & Mitręga & Mleczna & Dziechcinka & Vistula & Korzenica & Wiercica \\
\hline Ptychopteridae & - & 0.006 & 0.008 & - & - & - & - & - \\
\hline Scatophagidae & 0.350 & 0.013 & 0.011 & 0.018 & 0.006 & 0.115 & 0.183 & 0.053 \\
\hline Sciomyzidae & 0.016 & 0.004 & 0.009 & 0.003 & - & 0.009 & 0.011 & - \\
\hline Simuliidae & - & 65.772 & 22.491 & 2.489 & 22.699 & 4.436 & 11.404 & 17.120 \\
\hline Stratomyidae & 0.049 & 0.001 & 0.009 & 0.015 & 0.003 & - & - & 0.003 \\
\hline Tabanidae & 0.961 & 0.002 & 0.081 & 0.020 & 0.003 & 0.023 & - & 0.009 \\
\hline Thaumaleiidae & - & 0.002 & 0.004 & 0.001 & 0.014 & 0.012 & - & 0.057 \\
\hline Tipulidae & - & 0.002 & 1.270 & 0.004 & 0.011 & 0.023 & 0.010 & 0.021 \\
\hline Hymenoptera & - & - & - & 0.001 & - & - & - & - \\
\hline \multicolumn{9}{|l|}{ Lepidoptera } \\
\hline $\begin{array}{l}\text { Acentria ephemerella } \\
\quad \text { (Denis \& Schiffermuller, 1775) }\end{array}$ & - & - & 0.004 & - & 0.006 & - & 0.003 & 0.002 \\
\hline Cataclysta lemnata (Linnaeus, 1758) & - & - & - & - & - & - & 0.001 & 0.008 \\
\hline Nymphula sp. & 0.039 & 0.005 & 0.055 & 0.021 & - & - & 0.147 & 0.066 \\
\hline Paraponyx sp. & - & - & - & 0.001 & - & - & 0.003 & 0.003 \\
\hline \multicolumn{9}{|l|}{ Trichoptera } \\
\hline Baeridae & - & - & 0.781 & - & - & 0.014 & - & - \\
\hline Brachycentridae & - & - & - & - & - & 1.448 & - & 0.033 \\
\hline Ecnomus tenellus (Rambur, 1842) & 0.007 & 0.001 & 0.160 & 0.005 & 0.022 & 0.017 & 1.500 & 0.599 \\
\hline Glossosomatidae & - & - & 0.004 & - & 4.554 & 0.530 & 0.003 & \\
\hline Goeridae & - & 0.002 & 0.021 & - & 0.034 & 1.477 & 0.310 & 0.122 \\
\hline Hydropsychidae & - & 0.836 & 0.600 & 0.067 & 0.383 & 1.981 & 2.600 & 0.501 \\
\hline Hydroptilidae & - & 0.005 & 1.072 & - & 0.008 & 0.104 & 3.851 & 1.354 \\
\hline Lepidostomatidae & - & 0.003 & - & - & 0.012 & 0.651 & - & 0.021 \\
\hline Leptoceridae & - & 0.027 & 0.477 & 0.035 & 0.027 & 1.059 & 1.500 & 0.061 \\
\hline Limnephilidae & 0.013 & 0.678 & 2.118 & 0.004 & 0.778 & 1.212 & 0.645 & 1.393 \\
\hline Molanidae & - & - & - & - & - & - & - & 0.001 \\
\hline Odontocerum albicorne (Scopoli, 1763) & - & - & 0.006 & - & 0.115 & 0.377 & - & 0.013 \\
\hline Philopotamidae & - & - & - & - & 0.014 & 0.222 & - & - \\
\hline Phryganeidae & - & 0.009 & 0.002 & - & - & - & 0.010 & 0.012 \\
\hline Polycentropodidae & - & 0.046 & 0.243 & 0.003 & 0.026 & 0.449 & 0.034 & 0.046 \\
\hline Psychomyidae & - & 0.008 & 0.013 & - & 0.005 & 0.029 & 0.018 & 0.029 \\
\hline Ptilocolepidae & - & - & - & - & 0.008 & 0.052 & - & - \\
\hline Rhyacophilidae & - & 0.054 & - & - & 0.208 & 0.711 & - & 0.003 \\
\hline Sericostomatidae & - & 0.026 & 0.002 & - & 0.681 & 0.371 & 0.110 & 0.183 \\
\hline \multicolumn{9}{|l|}{ Megaloptera } \\
\hline Sialis sp. & - & 0.063 & 0.074 & - & 0.015 & 0.035 & 0.025 & 0.007 \\
\hline \multicolumn{9}{|l|}{ Neuroptera } \\
\hline Osmylus fluvicephalus (Scopoli, 1763) & - & - & - & - & - & - & - & 0.004 \\
\hline \multicolumn{9}{|l|}{ Heteroptera } \\
\hline Corixidae & 0.056 & 0.006 & 0.042 & 0.001 & - & 0.006 & 0.038 & 0.004 \\
\hline Gerris sp. & 0.216 & 0.002 & 0.079 & 0.043 & 0.010 & - & 0.059 & 0.067 \\
\hline Hydrometra sp. & - & - & 0.004 & 0.002 & - & - & - & - \\
\hline Ilyocoris cimicoides (Linnaeus, 1758) & - & - & - & 0.015 & - & - & 0.045 & - \\
\hline Mesoveliidae & - & 0.001 & - & - & - & - & 0.008 & 0.010 \\
\hline
\end{tabular}


Table 5 (continued)

\begin{tabular}{|c|c|c|c|c|c|c|c|c|}
\hline Taxon & Bolina & Centuria & Mitręga & Mleczna & Dziechcinka & Vistula & Korzenica & Wiercica \\
\hline Nepa cinerea Linnaeus, 1758 & 0.033 & - & 0.040 & 0.012 & - & - & 0.010 & 0.017 \\
\hline Noteridae & 0.026 & - & 0.008 & 0.013 & 0.002 & - & 0.008 & 0.011 \\
\hline Notonecta sp. & 0.065 & 0.001 & 0.040 & 0.042 & - & - & 0.034 & 0.009 \\
\hline Plea minutissima (Leach, 1817) & - & - & - & - & - & - & 0.008 & - \\
\hline Veliidae & - & - & 0.015 & 0.001 & - & - & 0.006 & 0.015 \\
\hline \multicolumn{9}{|l|}{ Plecoptera } \\
\hline Chloroperlidae & - & - & - & - & 0.021 & 0.023 & - & - \\
\hline Leuctridae & - & 0.227 & 0.008 & - & 1.023 & 8.179 & 0.001 & 0.946 \\
\hline Nemouridae & - & 1.974 & 3.276 & 0.005 & 1.886 & 7.954 & 1.863 & 5.017 \\
\hline Perlidae & - & - & - & - & 0.005 & 0.058 & - & - \\
\hline Perlodidae & - & - & - & - & 0.006 & 0.156 & - & - \\
\hline \multicolumn{9}{|l|}{ Ephemeroptera } \\
\hline Ameletidae & - & - & 0.026 & - & 0.001 & 0.014 & - & - \\
\hline Baetidae & 0.013 & 2.655 & 0.993 & 0.676 & 1.505 & 2.960 & 2.211 & 1.626 \\
\hline Caenidae & - & - & 2.025 & 0.006 & 0.001 & 0.346 & 0.105 & 0.006 \\
\hline Ephemera sp. & - & 0.022 & 0.009 & - & 0.015 & 0.040 & 0.171 & - \\
\hline Ephemerellidae & - & 0.038 & 0.042 & - & 0.497 & 1.756 & 0.022 & 0.400 \\
\hline Heptageniidae & - & 0.023 & 0.011 & - & 0.357 & 1.085 & - & 0.031 \\
\hline Leptophlebiidae & - & 0.024 & 0.402 & 0.001 & 0.115 & 1.068 & 1.135 & 0.035 \\
\hline Potamanthidae & - & - & - & - & - & - & 0.001 & - \\
\hline Siphlonuridae & - & 0.001 & 0.004 & - & - & 0.014 & - & - \\
\hline \multicolumn{9}{|l|}{ Odonata } \\
\hline Aeshnidae & 0.010 & - & 0.030 & 0.001 & - & - & 0.010 & - \\
\hline Calopterygidae & - & - & 0.221 & 0.005 & - & - & 0.229 & 0.247 \\
\hline Coenagrionidae & 1.246 & 0.004 & 0.091 & 0.825 & - & - & 0.527 & - \\
\hline Corduliidae & - & - & - & - & - & - & 0.007 & - \\
\hline Gomphidae & - & - & 0.025 & - & - & - & - & 0.004 \\
\hline Lestidae & 0.020 & - & - & - & - & - & 0.017 & - \\
\hline Libellulidae & 0.052 & - & - & - & - & - & 0.011 & - \\
\hline Platycnemis pennipes Pallas, 1771 & 0.154 & 0.005 & 0.002 & 0.015 & - & 0.006 & 0.008 & 0.015 \\
\hline Nematoda & 0.016 & 0.025 & 0.349 & 0.308 & 0.044 & 0.078 & 1.221 & 0.060 \\
\hline Nematomorpha & - & 0.826 & 0.211 & 0.030 & 0.021 & 0.046 & 0.808 & 0.137 \\
\hline Acantocephala & - & - & - & 0.022 & 0.272 & - & 0.014 & 0.002 \\
\hline \multicolumn{9}{|l|}{ Annelida } \\
\hline Erpobdellidae & - & 0.325 & 1.521 & 0.334 & 0.001 & 0.009 & 0.238 & 0.295 \\
\hline Haemopidae & - & 0.002 & 0.019 & 0.001 & - & - & 0.007 & 0.045 \\
\hline Glossiphoniidae & - & 0.176 & 0.226 & 0.310 & - & 0.009 & 0.299 & 0.042 \\
\hline Piscicolidae & - & - & - & 0.003 & - & - & - & - \\
\hline Oligochaeta & 27.290 & 0.763 & 23.784 & 21.470 & 0.843 & 2.030 & 7.570 & 4.010 \\
\hline \multicolumn{9}{|l|}{ Bivalvia } \\
\hline Anodonta anatina (Linnaeus, 1758) & - & - & 0.009 & 0.001 & - & - & - & - \\
\hline Musculium lacustre (Müller, 1774) & - & 0.003 & - & 0.023 & - & - & - & - \\
\hline Pisidium sp. & - & 0.615 & 1.927 & 1.352 & 0.121 & 0.458 & 2.248 & 0.795 \\
\hline Sphaerium sp. & - & 0.112 & 0.057 & 0.611 & 0.040 & 0.012 & 0.001 & 0.009 \\
\hline
\end{tabular}


Table 5 (continued)

\begin{tabular}{|c|c|c|c|c|c|c|c|c|}
\hline Taxon & Bolina & Centuria & Mitręga & Mleczna & Dziechcinka & Vistula & Korzenica & Wiercica \\
\hline \multicolumn{9}{|l|}{ Gastropoda } \\
\hline Acroloxus lacustris (Linnaeus, 1758) & - & - & 0.034 & - & - & - & - & 0.217 \\
\hline Ancylus fluviatilis Müller, 1774 & - & 0.009 & - & - & 0.081 & 0.173 & - & - \\
\hline Anisus spirorbis (Linnaeus, 1758) & - & - & - & - & - & - & 0.001 & - \\
\hline Anisus vortex (Linnaeus, 1758) & - & - & - & - & - & - & - & 0.061 \\
\hline Bathyomphalus contortus (Linnaeus, 1758) & & 0.011 & - & 0.001 & - & - & - & 0.090 \\
\hline Bithynia tentaculata (Linnaeus, 1758) & - & - & - & 0.379 & - & - & 0.003 & 0.010 \\
\hline Bythinella sp. & - & - & - & - & 0.107 & 0.069 & - & 0.002 \\
\hline Ferrissia fragilis (Tryon, 1863) & - & - & - & - & - & - & 0.003 & - \\
\hline Galba truncatula (Müller, 1774) & - & - & - & - & 0.002 & 0.006 & - & - \\
\hline Gyraulus albus (Müller, 1774) & - & 0.003 & 1.098 & 0.006 & - & 0.109 & 1.046 & 0.003 \\
\hline Gyraulus crista (Linnaeus, 1758) & - & 0.001 & 0.013 & 0.178 & - & - & - & - \\
\hline Hippeutis complanatus (Linnaeus, 1758) & - & - & 0.040 & - & - & - & 0.014 & - \\
\hline Lymnaea stagnalis (Linnaeus, 1758) & - & - & - & 0.014 & - & - & 0.238 & 0.012 \\
\hline Lymnaeidae & - & 0.008 & 0.008 & - & 0.007 & - & - & 0.014 \\
\hline Physa acuta (Draparnaud, 1805) & - & - & - & 0.046 & - & - & - & - \\
\hline Physa fontinalis (Linnaeus, 1758) & - & - & 0.023 & - & - & - & - & 0.066 \\
\hline Planorbarius corneus (Linnaeus, 1758) & - & 0.002 & 0.153 & 0.146 & - & - & 0.046 & 0.005 \\
\hline Potamopyrgus antipodarum (Gray, 1843) & 2.514 & - & - & 24.436 & - & - & - & - \\
\hline Radix auricularia (Linnaeus, 1758) & - & 0.008 & 0.015 & 0.001 & - & 0.006 & - & 0.006 \\
\hline Radix balthica (Linnaeus, 1758) & - & 0.002 & - & 0.349 & - & 0.003 & - & 0.070 \\
\hline Segmentina nitida (Müller, 1774) & - & - & 0.023 & - & - & - & 0.006 & - \\
\hline Stagnicola palustris (Müller, 1774) & - & 0.007 & - & - & - & - & - & 0.179 \\
\hline Stagnicola sp. & - & - & 0.004 & - & - & - & - & - \\
\hline \multicolumn{9}{|l|}{ Platyhelminthes } \\
\hline Dendrocoelum lacteum (Müller, 1773) & - & - & - & 0.001 & 0.001 & - & - & 0.006 \\
\hline Dugesia sp. & - & 0.065 & 0.023 & 0.065 & 0.067 & 0.043 & 0.064 & 0.665 \\
\hline Phagocata vitta (Duges, 1830) & - & 0.001 & - & - & 0.004 & 0.043 & - & - \\
\hline Planaria torva (Müller, 1773) & - & 0.006 & - & 0.011 & - & 0.012 & 0.038 & 0.001 \\
\hline \multicolumn{9}{|l|}{ Cnidaria } \\
\hline Hydrozoa & - & 0.004 & 0.504 & 0.003 & - & - & 0.572 & 0.147 \\
\hline \multicolumn{9}{|l|}{ Porifera } \\
\hline Spongillidae & - & - & - & - & - & - & - & 0.001 \\
\hline
\end{tabular}


Open Access This article is licensed under a Creative Commons Attribution 4.0 International License, which permits use, sharing, adaptation, distribution and reproduction in any medium or format, as long as you give appropriate credit to the original author(s) and the source, provide a link to the Creative Commons licence, and indicate if changes were made. The images or other third party material in this article are included in the article's Creative Commons licence, unless indicated otherwise in a credit line to the material. If material is not included in the article's Creative Commons licence and your intended use is not permitted by statutory regulation or exceeds the permitted use, you will need to obtain permission directly from the copyright holder. To view a copy of this licence, visit http://creativecommons. org/licenses/by/4.0/.

\section{References}

Aldridge, D. C. (2000). The impacts of dredging and weed cutting on a population of freshwater mussels (Bivalvia: Unionidae). Biological Conservation, 95(3), 247-257. https://doi. org/10.1016/S0006-3207(00)00045-8.

Allan, J. D., \& Castillo, M. M. (2009). Stream ecology: Structure and function of running waters. Dordrecht: Springer. https://doi.org/10.1007/978-1-4020-5583-6.

Alves Dias, P., Kanellopoulos, K., Medarac, H., Kapetaki, Z., Miranda-Barbosa, E., Shortall, R., et al. (2018). EU coal regions: Opportunities and challenges ahead. Luxembourg: Publications Office of the European Union. https://doi. org/10.2760/064809.

Amoatey, P., \& Baawain, M. S. (2019). Effects of pollution on freshwater aquatic organisms. Water Environment Research, 91(10), 1272-1287. https://doi.org/10.1002 /wer.1221.

Arle, J., \& Wagner, F. (2013). Effects of anthropogenic salinisation on the ecological status of macroinvertebrate assemblages in the Werra River (Thuringia, Germany). Hydrobiologia, 701(1), 129-148. https://doi.org/10.1007 /s10750-012-1265-z.

Bąk, M., Halabowski, D., Kryk, A., Lewin, I., \& Sowa, A. (2020). Mining salinisation of rivers: Its impact on diatom (Bacillariophyta) assemblages. Fottea, 20(1), 1-16. https://doi.org/10.5507/fot.2019.010.

Bäthe, J., \& Coring, E. (2011). Biological effects of anthropogenic salt-load on the aquatic Fauna: A synthesis of 17 years of biological survey on the rivers Werra and Weser. Limnologica, 41(2), 125-133. https://doi.org/10.1016/j. limno.2010.07.005.

Battaglia, M., Hose, G. C., Turak, E., \& Warden, B. (2005). Depauperate macroinvertebrates in a mine affected stream: clean water may be the key to recovery. Environmental Pollution, 138(1), 132-141. https://doi.org/10.1016/j. envpol.2005.02.022.

Berger, E., Frör, O., \& Schäfer, R. B. (2019). Salinity impacts on river ecosystem processes: a critical mini-review. Philosophical Transactions of the Royal Society B: Biological Sciences, 374(1764), 20180010. https://doi. org/10.1098/rstb.2018.0010.
Blakeslee, C. J., Galbraith, H. S., Robertson, L. S., \& White, B. S. J. (2013). The effects of salinity exposure on multiple life stages of a common freshwater mussel, Elliptio complanata. Environmental Toxicology and Chemistry, 32(12), 28492854. https://doi.org/10.1002/etc.2381.

Briggs, J. C. (2017). Emergence of a sixth mass extinction? Biological Journal of the Linnean Society, 122(2), 243248. https://doi.org/10.1093/biolinnean/blx063.

Cañedo-Argüelles, M., Brucet, S., Carrasco, S., Flor-Arnau, N., Ordeix, M., Ponsá, S., et al. (2013). Salinisation of rivers: an urgent ecological issue. Environmental Pollution, 173, 157167. https://doi.org/10.1016/j.envpol.2016.12.072.

Cañedo-Argüelles, M., Hawkins, C. P., Kefford, B. J., Schäfer, R. B., Dyack, B. J., Brucet, S., et al. (2016). Saving freshwater from salts. Science, 351(6276), 914-916. https://doi. org/10.1126/science.aad3488.

Cañedo-Argüelles, M., Brucet, S., Carrasco, S., Flor-Arnau, N., Ordeix, M., Ponsá, S., et al. (2017). Effects of potash mining on river ecosystems: an experimental study. Environmental Pollution, 224, 759-770. https://doi.org/10.1016/j. envpol.2016.12.072.

Ceballos, G., Ehrlich, P. R., Barnosky, A. D., García, A., Pringle, R. M., \& Palmer, T. M. (2015). Accelerated modern humaninduced species losses: entering the sixth mass extinction. Science Advances, 1(5), e1400253. https://doi.org/10.1126 /sciadv.1400253.

Cosgrove, P. J., \& Hastie, L. C. (2001). Conservation of threatened freshwater pearl mussel populations: river management, mussel translocation and conflict resolution. Biological Conservation, 99(2), 183-190. https://doi.org/10.1016 /S0006-3207(00)00174-9.

de Nijs, M. A. J., \& Pietrzak, J. D. (2012). Saltwater intrusion and ETM dynamics in a tidally-energetic stratified estuary. Ocean Modelling, 49-50, 60-85. https://doi.org/10.1016/j. ocemod.2012.03.004.

Directive. (2000). Directive 2000/60/EC of the European Parliament and of the Council of 23 October 2000 establishing a framework for Community action in the field of water policy. Official Journal of the European Communities, L327, $1-72$.

Douda, K. (2010). Effects of nitrate nitrogen pollution on Central European unionid bivalves revealed by distributional data and acute toxicity testing. Aquatic Conservation: Marine and Freshwater Ecosystems, 20(2), 189-197. https://doi. org/10.1002/aqc. 1076 .

Dudgeon, D., Arthington, A. H., Gessner, M. O., Kawabata, Z. I., Knowler, D. J., Leveque, C., et al. (2007). Freshwater biodiversity: importance, threats, status and conservation challenges. Biological Reviews, 81(2), 163-182. https://doi. org/10.1017/S1464793105006950.

Dulias, R. (2016). The Impact of Mining on the Landscape: A Study of the Upper Silesian Coal Basin in Poland. Switzerland: Springer. https://doi.org/10.1007/978-3-31929541-1.

Eggers, T. O., \& Martens, A. (2001). A key to the freshwater Amphipoda (Crustacea) of Germany. Lauterbornia, 42, 170 .

Eurostat Statistics Expained. (2020). Coal production and consumption statistics at https://ec.europa.eu/eurostat/statisticsexplained/index.php?title=Coal_production_and 
consumption_statistics\#Consumption_and production_of hard_coa. Accessed 15 Oct 2020.

Fischer, G., Tubiello, F. N., van Velthuizen, H., \& Wiberg, D. A. (2007). Climate change impacts on irrigation water requirements: effects of mitigation, 1990-2080. Technological Forecasting and Social Change, 74(7), 1083-1107. https://doi.org/10.1016/j.techfore.2006.05.021.

Galloway, J. N., Townsend, A. R., Erisman, J. W., Bekunda, M., Cai, Z., Freney, J. R., et al. (2008). Transformation of the nitrogen cycle: recent trends, questions, and potential solutions. Science, 320(5878), 889-892. https://doi.org/10.1126 /science.1136674.

Geist, J. (2014). Trends and directions in water quality and habitat management in the context of the European Water Framework Directive. Fisheries, 39(5), 219-220. https://doi.org/10.1080/03632415.2014.903838.

Geist, J., \& Auerswald, K. (2007). Physicochemical stream bed characteristics and recruitment of the freshwater pearl mussel (Margaritifera margaritifera). Freshwater Biology, 52(12), 2299-2316. https://doi.org/10.1111/j.13652427.2007.01812.x.

Geist, J., \& Kuehn, R. (2005). Genetic diversity and differentiation of central European freshwater pearl mussel (Margaritifera margaritifera L.) populations: implications for conservation and management. Molecular Ecology, 14(2), 425-439. https://doi.org/10.1111/j.1365-294X.2004.02420.x.

Grace, M. R., Hislop, T. M., Hart, B. T., \& Beckett, R. (1997). Effect of saline groundwater on the aggregation and settling of suspended particles in a turbid Australian river. Colloids and Surfaces A: Physicochemical and Engineering Aspects, 120(1-3), 123-141. https://doi.org/10.1016/S0927-7757(96 )03863-0.

Grizzetti, B., Bouraoui, F., Billen, G., Van Grinsven, H., Cardoso, A. C., Thieu, V., et al. (2011). Nitrogen as a threat to European water quality. In M. A. Sutton, C. M. Howard, J. W. Erisman, G. Billen, A. Bleeker, P. Grennfelt, et al. (Eds.), The European nitrogen assessment (pp. 379-404). Cambridge: Cambridge University Press. https://doi. org/10.1017/CBO9780511976988.020.

Halabowski, D., \& Lewin, I. (2020). Impact of anthropogenic transformations on the vegetation of selected abiotic types of rivers in two ecoregions (Southern Poland). Knowledge and Management of Aquatic Ecosystems, 421, 35. https://oi. org $/ 10.1051 / \mathrm{kmae} / 2020026$.

Halabowski, D., Bielańska-Grajner, I., \& Lewin, I. (2019). Effect of underground salty mine water on the rotifer communities in the Bolina River (Upper Silesia, Southern Poland). Knowledge and Management of Aquatic Ecosystems, 420, 31. https://doi.org/10.1051/kmae/2019023.

Halabowski, D., Lewin, I., Buczyński, P., Krodkiewska, M., Płaska, W., Sowa, A., et al. (2020). Impact of the discharge of salinised coal mine waters on the structure of the macroinvertebrate communities in an urban river (Central Europe). Water, Air, \& Soil Pollution, 231, 5. https://doi.org/10.1007 /s11270-019-4373-9.

Harat, A., \& Grmela, A. (2008). Impact of mine water from the Upper Silesian Coal Basin areas on change quality of water in
Olza river in years 2000-2007. Natural Environment Monitoring, 9, 57-62.

Hart, B. T., Bailey, P., Edwards, R., Hortle, K., James, K., McMahon, A., et al. (1991). A review of the salt sensitivity of the Australian freshwater biota. Hydrobiologia, 210(1-2), 105-144. https://doi.org/10.1007/BF00014327.

Hauer, F. \& Lamberti, G. (2007). Methods in stream ecology (Second ed.). Amsterdam-Boston-Heidelberg-LondonNew York-Oxford-Paris-San Diego-San FranciscoSingapore-Sydney-Tokyo: Academic Press, Elsevier. doi: https://doi.org/10.1016/B978-0-12-332908-0.X5001-3.

Herbert, E. R., Boon, P., Burgin, A. J., Neubauer, S. C., Franklin, R. B., Ardon, M., et al. (2015). A global perspective on wetland salinization: ecological consequences of a growing threat to freshwater wetlands. Ecosphere, 6(10), 1-43. https://doi.org/10.1890/ES14-00534.1.

Hering, D., Johnson, R. K., Kramm, S., Schmutz, S., Szoszkiewicz, K., \& Verdonschot, P. F. M. (2006). Assessment of European streams with diatoms, macrophytes, macroinvertebrates and fish: a comparative metric-based analysis of organism response to stress. Freshwater Biology, 51(9), 1757-1785. https://doi.org/10.1111/j.13652427.2006.01610.x.

James, K. R., Cant, B., \& Ryan, T. (2003). Responses of freshwater biota to rising salinity levels and implications for saline water management: a review. Australian Journal of Botany, 51, 703-713. https://doi.org/10.1071/BT02110.

Kang, S. R., \& King, S. L. (2012). Influence of salinity and prey presence on the survival of aquatic macroinvertebrates of a freshwater marsh. Aquatic Ecology, 46, 411-420. https://doi. org/10.1007/s10452-012-9410-3.

Kefford, B. J., Marchant, R., Schäfer, R. B., Metzeling, L., Dunlop, J. E., Choy, S. C., et al. (2011). The definition of species richness used by species sensitivity distributions approximates observed effects of salinity on stream macroinvertebrates. Environmental Pollution, 159(1), 302-310. https://doi.org/10.1016/j.envpol.2010.08.025.

Kołodziejczyk, A., \& Koperski, P. (2000). Bezkręgowce Stodkowodne Polski. Klucz do Oznaczania oraz Podstawy Biologii i Ekologii Makrofauny. Warszawa: Wydawnictwo Uniwersytetu Warszawskiego (in Polish).

Kumaraswamy, T. R., Javeed, S., Javaid, M., \& Naika, K. (2020). Impact of pollution on quality of freshwater ecosystems. In H. Qadri, R. A. Bhat, M. A. Mehmood, \& G. H. Dar (Eds.), Fresh water pollution dynamics and remediation (pp. 6981). Singapore: Springer. https://doi.org/10.1007/978-98113-8277-2_5.

Ladrera, R., Cañedo-Argüelles, M., \& Prat, N. (2017). Impact of potash mining in streams: the Llobregat basin (northeast Spain) as a case study. Journal of Limnology, 76(2), 343354. https://doi.org/10.4081/jlimnol.2016.1525.

Lewin, I., Czerniawska-Kusza, I., Szoszkiewicz, K., Ławniczak, A. E., \& Jusik, S. (2013). Biological indices applied to benthic macroinvertebrates at reference conditions of mountain streams in two ecoregions (Poland, the Slovak Republic). Hydrobiologia, 709, 183-200. https://doi.org/10.1007 /s10750-013-1448-2. 
Lewin, I., Jusik, S., Szoszkiewicz, K., Czerniawska-Kusza, I., \& Ławniczak, A. E. (2014). Application of the new multimetric MMI_PL index for biological water quality assessment in reference and human-impacted streams (Poland, the Slovak Republic). Limnologica, 49, 42-51. https://doi.org/10.1016/j. limno.2014.09.001.

Lewin, I., Szoszkiewicz, K., Jusik, S., \& Ławniczak, A. E. (2015). Influence of selected environmental factors on macroinvertebrates in mountain streams. Open Life Sciences, 10, 99-111. https://doi.org/10.1515/biol-2015-0008.

Lewin, I., Halabowski, D., \& Rymarski, Z. (2018). The first records of the occurrence of a North American invader Gammarus tigrinus Sexton, 1939 in the tributaries of the upper Vistula River. Knowledge and Management of Aquatic Ecosystems, 419, 31. https://doi.org/10.1051 $/ \mathrm{kmae} / 2018021$.

Lioy, P. J., \& Smith, K. R. (2013). A Discussion of exposure science in the 21 st century: a vision and a strategy. Environmental Health Perspectives, 121(4), 405-409.

Lopes-Lima, M., Sousa, R., Geist, J., Aldridge, D., Araujo, R., Bergengren, J., et al. (2017). Conservation status of freshwater mussels in Europe: state of the art and future challenges: conservation of European freshwater mussels. Biological Reviews, 92(1), 572-607. https://doi.org/10.1111/brv.12244.

Malmqvist, B., \& Rundle, S. (2002). Threats to the running water ecosystems of the world. Environmental Conservation, 29(2), 134-153. https://doi.org/10.1017 /S0376892902000097.

Mauch, E. (2017). Aquatic Diptera larvae in Central, Northwest and North Europe. The forms and their identification, a survey. Lauterbornia, 83, 1-404. (in German).

Maxwell, S. L., Fuller, R. A., Brooks, T. M., \& Watson, J. E. M. (2016). Biodiversity: the ravages of guns, nets and bulldozers. Nature, 536(7615), 143-145. https://doi. org/10.1038/536143a.

McCune, B., \& Grace, J. (2002). Analysis of ecological communities. Gleneden Beach, Oregon: Mjm Software Design.

McGinley, P. C. (2011). Climate change and the war on coal: exploring the dark side. Vermont Journal of Environmental Law, 13, 255-332.

Meiggs, D., \& Taillefert, M. (2011). The effect of riverine discharge on biogeochemical processes in estuarine sediments. Limnology and Oceanography, 56(5), 1797-1810. https://doi.org/10.4319/lo.2011.56.5.1797.

Myślińska, E. (2001). Organic and laboratory land testing methods. Warszawa: Państwowe Wydawnictwo Naukowe (in Polish).

Neubauer, S. C., \& Craft, C. B. (2009). Global change and tidal freshwater wetlands: scenarios and impacts. In A. Barendregt, D. F. Whigham, \& A. H. Baldwin (Eds.), Tidal freshwater wetlands (pp. 253-266). Leiden: Backhuys Publishers.

Nieto, C., Ovando, X. M. C., Loyola, R., Izquierdo, A., Romero, F., Molineri, C., et al. (2017). The role of macroinvertebrates for conservation of freshwater systems. Ecology and Evolution, 7(14), 5502-5513. https://doi.org/10.1002 lece3.3101.
Nijssen, B., O’Donnell, G. M., Hamlet, A. F., \& Lettenmaier, D. P. (2001). Hydrologic sensitivity of global rivers to climate change. Climatic Change, 50, 143-175. https://doi. org/10.1023/A:1010616428763.

Paller, M. H., Sterrett, S. C., Tuberville, T. D., Fletcher, D. E., \& Grosse, A. M. (2014). Effects of disturbance at two spatial scales on macroinvertebrate and fish metrics of stream health. Journal of Freshwater Ecology, 29(1), 83-100. https://doi. org/10.1080/02705060.2013.832707.

Payne, J. L., Bush, A. M., Heim, N. A., Knope, M. L., \& McCauley, D. J. (2016). Ecological selectivity of the emerging mass extinction in the oceans. Science, 353(6305), 1284 1286. https://doi.org/10.1126/science.aaf2416.

Piechocki, A., \& Wawrzyniak-Wydrowska, B. (2016). Guide to freshwater and marine Mollusca of Poland. Poznań: Bogucki Wydawnictwo Naukowe.

Pinder, A. M., Halse, S. A., McRae, J. M., \& Shiel, R. J. (2005). Occurrence of aquatic invertebrates of the wheatbelt region of Western Australia in relation to salinity. Hydrobiologia, 543(1), 1-24. https://doi. org/10.1007/s10750-004-5712-3.

Piscart, C., Moreteau, J.-C., \& Beisel, J.-N. (2005). Biodiversity and structure of macroinvertebrate communities along a small permanent salinity gradient (Meurthe River, France). Hydrobiologia, 551, 227-236. https://doi.org/10.1007 /s10750-005-4463-0.

Pynnönen, K. (1995). Effect of $\mathrm{pH}$, hardness and maternal preexposure on the toxicity of $\mathrm{Cd}, \mathrm{Cu}$ and $\mathrm{Zn}$ to the glochidial larvae of a freshwater clam Anodonta cygnea. Water Research, 29(1), 247-254. https://doi.org/10.1016/00431354(94)00126-R.

Rawer-Jost, C., Zenker, A., \& Böhmer, J. (2004). Reference conditions of German stream types analysed and revised with macroinvertebrate fauna. Limnologica, 34(4), 390-397. https://doi.org/10.1016/S0075-9511(04)80008-2.

Rewicz, T., Grabowski, M., Tończyk, G., Konopacka, A., \& Bącela-Spychalska, K. (2019). Gammarus tigrinus Sexton, 1939 continues its invasion in the Baltic Sea: first record from Bornholm (Denmark). BioInvasions Records, 8(4), 862-870. https://doi.org/10.3391/bir.2019.8.4.14.

Rozkošný, R. (1980). Klíč Vodních Larev Hmyzu. Praha: Československá Academie VĚD.

Rudolph, K., Coleman, C. O., Mamos, T., \& Grabowski, M. (2018). Description and post-glacial demography of Gammarus jazdzewskii sp. nov. (Crustacea: Amphipoda) from Central Europe. Systematics and Biodiversity, 16, 587-603. https://doi.org/10.1080/14772000.2018.1470118.

Schmeller, D. S., Loyau, A., Bao, K., Brack, W., Chatzinotas, A., De Vleeschouwer, F., et al. (2018). People, pollution and pathogens - Global change impacts in mountain freshwater ecosystems. Science of The Total Environment, 622-623, 756-763. https://doi.org/10.1016/j.scitotenv.2017.12.006.

Schuler, M. S., Cañedo-Argüelles, M., Hintz, W. D., Dyack, B., Birk, S., \& Relyea, R. A. (2019). Regulations are needed to protect freshwater ecosystems from salinization. Philosophical Transactions of the Royal Society B: Biological Sciences, 374(1764), 20180019. https://doi. org/10.1098/rstb.2018.0019. 
Sholkovitz, E. (1976). Flocculation of dissolved organic and inorganic matter during the mixing of river water and seawater. Geochimica et Cosmochimica Acta, 40(7), 831-845. https://doi.org/10.1016/0016-7037(76)90035-1.

Sowa, A., Krodkiewska, M., \& Halabowski, D. (2020). How does mining salinisation gradient affect the structure and functioning of macroinvertebrate communities? Water, Air, \& Soil Pollution, 231, 453. https://doi.org/10.1007/s11270-02004823-4.

Šporka, F., Pastuchová, Z., Hamerlík, L., Dobiašová, M., \& Beracko, P. (2009). Assessment of running waters (Slovakia) using benthic macroinvertebrates - derivation of ecological quality classes with respect to altitudinal gradients. Biologia, 64(6), 1196-1205. https://doi.org/10.2478 /s11756-009-0201-9.

Strayer, D. L. (2006). Challenges for freshwater invertebrate conservation. Freshwater Science, 25(2), 271-287. https://doi. org/10.1899/0887-3593(2006)25[271:CFFIC]2.0.CO;2.

Strozik, G. (2017). Reduction of saline waters discharge from coal mines through filling and sealing of underground voids. World Scientific News, 72, 498-512.

Szoszkiewicz, K., Jusik, S., Adynkiewicz-Piragas, M., Gebler, D., Achtenberg, K., Radecki-Pawlik, A., et al. (2017). Podrecznik oceny wód ptynacych $w$ oparciu o Hydromorfologiczny Indeks Rzeczny. Warszawa: Biblioteka Monitoringu Środowiska. (in Polish).

Szoszkiewicz, K., Jusik, S., Gebler, D., Achtenberg, K., Adynkiewicz-Piragas, M., Radecki-Pawlik, A., et al. (2020). Hydromorphological Index for Rivers (HIR): A new method for hydromorphological assessment and classification for flowing waters in Poland. Journal of Ecological Engineering, 21(8), 261-271. https://doi.org/10.12911 /22998993/126879.

Ter Braak, C. J. F., \& Smilauer, P. (2002). CANOCO Reference manual and CanoDraw for Windows user's guide: Software for canonical community ordination (version 4.5). Ithaca: Microcomputer Power.

Tończyk, G., Siciński, J., Grabowski, M., Jabłońska, A., Jażdżewski, K., Jurasz, W., et al. (2013). Klucz do oznaczania makrobezkregowców bentosowych dla potrzeb oceny stanu ekologicznego wód powierzchniowych. Warszawa: Główny Inspektorat Ochrony Środowiska (in Polish).

Vörösmarty, C. J., Green, P., Salisbury, J., \& Lammers, R. B. (2000). Global water resources: vulnerability from climate change and population growth. Science, 289(5477), 284 288. https://doi.org/10.1126/science.289.5477.284.

Ward, J. V., Tockner, K., Arscott, D. B., \& Claret, C. (2002). Riverine landscape diversity. Freshwater Biology, 47(4), 517-539. https://doi.org/10.1046/j.1365-2427.2002.00893.x.

Winemiller, K. O. (2018). Trends in biodiversity: freshwater. In D. A. Della Sala \& M. I. Goldstein (Eds.), The Encyclopedia of the anthropocene (pp. 151-161). UK, Oxford: Elsevier.

Publisher's Note Springer Nature remains neutral with regard to jurisdictional claims in published maps and institutional affiliations. 